Portland State University

PDXScholar

Environmental Science and Management

Faculty Publications and Presentations

$1-24-2014$

\title{
A Review of Urban Water Body Challenges and Approaches: (1) Rehabilitation and Remediation
}

\author{
Robert M. Hughes \\ Oregon State University \\ Susie Dunham \\ Oregon State University \\ Kathleen G. Maas-Hebner \\ Oregon State University \\ J. Alan Yeakley \\ Portland State University, yeakley@pdx.edu \\ Carl B. Schreck \\ U.S. Geological Survey
}

See next page for additional authors

Follow this and additional works at: https://pdxscholar.library.pdx.edu/esm_fac

Part of the Hydrology Commons, and the Water Resource Management Commons

Let us know how access to this document benefits you.

\section{Citation Details}

Robert M. Hughes, Susie Dunham, Kathleen G. Maas-Hebner, J. Alan Yeakley, Carl Schreck, Michael Harte, Nancy Molina, Clinton C. Shock, Victor W. Kaczynski \& Jeff Schaeffer (2014) A Review of Urban Water Body Challenges and Approaches: (1) Rehabilitation and Remediation, Fisheries, 39:1, 18-29

This Article is brought to you for free and open access. It has been accepted for inclusion in Environmental Science and Management Faculty Publications and Presentations by an authorized administrator of PDXScholar. Please contact us if we can make this document more accessible: pdxscholar@pdx.edu. 


\section{Authors}

Robert M. Hughes, Susie Dunham, Kathleen G. Maas-Hebner, J. Alan Yeakley, Carl B. Schreck, Michael Harte, Nancy Molina, Clinton C. Shock, Victor W. Kaczynski, and Jeff Schaeffer 


\section{A Review of Urban Water Body Challenges and Approaches: (1) Rehabilitation and Remediation}

\author{
Robert M. Hughes \\ Department of Fisheries and Wildlife, Oregon State University, and Amnis \\ Opes Institute, 2895 SE Glenn, Corvallis, OR 97333. E-mail: hughes.bob@ \\ amnisopes.com
}

\section{Susie Dunham and Kathleen G. Maas-Hebner}

Department of Fisheries and Wildlife, Oregon State University, Corvallis, OR

\section{J. Alan Yeakley}

Department of Environmental Science and Management, Portland State University, Portland, OR

\section{Carl Schreck}

Oregon Cooperative Fish and Wildlife Research Unit, U.S. Geological Survey, Oregon State University, Corvallis, OR

\section{Michael Harte}

College of Earth, Ocean and Atmospheric Science, Oregon State University, Corvallis, OR

\section{Nancy Molina}

Cascadia Ecosystems, Gresham, OR

\section{Clinton C. Shock}

Department of Crop and Soil Science, Oregon State University, Ontario, OR

\section{Victor W. Kaczynski}

Independent Consultant, Parkdale, OR

\section{Jeff Schaeffer}

USGS Great Lakes Science Center, Ann Arbor, MI

\section{Revisión de Enfoques y Retos en el Estudio de Cuerpos de Agua Urbanos: (1) Rehabilitación y Remediación}

RESUMEN: se hace una revisión de cómo la urbanización altera los ecosistemas acuáticos, así como también de las acciones que los administradores pueden tomar para remediar el problema de las aguas urbanas. La urbanización afecta los ríos a través de la alteración de procesos longitudinales y laterales que, a su vez, modifican la hidrología, hábitat y química del agua; estos efectos crean factores químicos y fisicos de estrés que perturban la biota. Los ríos urbanos suelen estar sujetos a múltiples factores de estrés que colectivamente se conocen como "síndrome del rio urbano" en el cual no existe dominancia de un solo factor de degradación. Los administradores de recursos naturales tienen diversas formas de combatir este síndrome. Estos enfoques van desde protección de cuencas enteras hasta rehabilitación de hábitats a gran escala, pero la prescripción debe ser consistente con la escala de los factores que están causando el problema, y es probable que los resultados no sean inmediatos dado que los tiempos de recuperación son prolongados. A pesar de que se está lejos de poder reconstruir las condiciones prístinas o de referencia, la rehabilitación de los ríos urbanos es un objetivo digno de perseguir ya que la toma de acciones adecuadas pueden lograr mejoras a los ecosistemas así como también un incremento en los beneficios que la sociedad humana obtiene de ellos.

\section{PREFACE}

This article and its companion (Hughes et al., 2014) stem from two reports published by Oregon's Independent Multidisciplinary Science Team (IMST 2010, 2012). The IMST was established by Oregon Revised Statute 541.409 in 1997 to provide independent, impartial advice to the state on scientific matters related to the Oregon Plan for Salmon and Watersheds. Previous IMST reports and agency reviews had focused on forest and agricultural land uses, and most of the rehabilitation efforts in the state were focused on those landscapes because of their great extent. The IMST recognized, however, that (1) most Oregon citizens live in cities and rural residential areas, (2) many important salmonid streams and rivers pass through those urban areas, and (3) urban areas play a key role in salmonid rehabilitation. Therefore, IMST (2010) was written to evaluate the science and how actions in urban and rural residential areas might aid salmonid recovery and catchment condition. Following completion of IMST (2010), the IMST held a workshop composed of municipal and state environmental managers 
and practitioners in 2011 to help fill gaps existing between the published scientific literature and what is known and needed by professionals actively working to rehabilitate aquatic resources in Oregon urban and rural residential areas. IMST (2012) summarized what was learned at that workshop and stimulated these two Fisheries articles, as well as a book (Yeakley et al., 2014).

\section{INTRODUCTION}

Human societies alter water bodies, the effects of which are dependent on the relative sizes of the urban centers versus the water bodies, their industries, and the natural and historical setting of the city. Because most people now live in cities and water is critical to human health and well-being, it is vital to maintain water quality in socially, economically, and ecologically effective ways. Although ecological effects of urbanization on aquatic ecosystems are described well in the scientific literature, approaches for rehabilitating and mitigating problems have received less attention and have not been considered in a practical, integrated manner. We review and summarize various approaches for reducing the effects of current urbanization on surface waters and discuss their benefits and limitations. Our review is divided into two major sections: (1) effects of urbanization on aquatic ecosystems and (2) actions for rehabilitating aquatic ecosystems in existing urban areas.

Urbanization results in a phenomenon commonly known as the "urban stream syndrome," whereby hydrographs become flashier (i.e., increased flow variability), water quality is degraded, channels are homogenized and incised, biological richness declines, and disturbance-tolerant and alien species increase in prevalence.

\section{EFFECTS OF URBANIZATION ON AQUATIC ECOSYSTEMS}

Understanding the effects of urbanization, or any land use, on aquatic ecosystems requires consideration of local- and catchment-scale effects, as well as current and historical effects. Civilizations began with cities around 9,000 YBP in the Middle East and China and 3,000 YBP in Mesoamerica. Many were hydraulic societies that modified their aquatic systems. This review, however, focuses on cities developing within the past 200 years. With over $50 \%$ of the world's population living in cities, and trending higher, urbanization is a global phenomenon (United Nations Population Division 2006; Grimm et al. 2008); $80 \%$ of U.S. citizens live in urban areas (Coles et al. 2012). High urban population density reduces the transportation cost of goods and services, offers greater employment opportunities, and increases information exchange that supports education and cultural enrichment (Grimm et al. 2008). However, urban areas fundamentally alter aquatic ecosystems - especially their hydrology, water quality, physical habitat quality, hydrological connectivity, ecological processes, and biota (Paul and Meyer 2001; Brown et al. 2005; Walsh et al. 2005; Chin 2006; Kaye et al. 2006; IMST 2010; R. A. Francis 2012; Yeakley et al., 2014).
These multifactor stressors and complex ecosystem responses are called "syndromes" (Rapport et al. 1985; Regier et al. 2013). Urbanization results in a phenomenon commonly known as the "urban stream syndrome" (Walsh et al. 2005), whereby hydrographs become flashier (i.e., increased flow variability), water quality is degraded, channels are homogenized and incised, biological richness declines, and disturbance-tolerant and alien species increase in prevalence. This syndrome may begin under even low levels of disturbance; for example, Stanfield et al. (2006) and Stranko et al. (2008) found that only 4\%-9\% impervious catchment cover sufficed to eliminate salmonids from Ontario and Maryland streams. Residential development also simplifies the riparian and nearshore zones of lakes by installing retaining walls and by reducing riparian vegetation, shoreline complexity, and snags (Jennings et al. 1999, 2003; T. B. Francis and Schindler 2006), which in turn alter fish and macroinvertebrate assemblages (Whittier et al. 1997; Jennings et al. 1999; Brauns et al. 2007). Watershed damage occurs because urbanization alters catchment hydrology (Groffman et al. 2003; Walsh et al. 2005), soil conditions (IMST 2010), vegetation composition and cover (Booth et al. 2002), atmospheric chemistry (Kaye et al. 2006; Grimm et al. 2008), elemental mass balances and cycling (Groffman et al. 2003; Hook and Yeakley 2005), and riparian corridors (Bryce et al. 2002; Hennings and Edge 2003; Ozawa and Yeakley 2007). These alterations result in an urban land syndrome with simplified, compacted, and more mineralized soils having lower water retention capability, increased atmospheric deposition of pollutants, and replacement of natural vegetation structure with anthropogenic structures and impervious surfaces, culminating with replacement of native biota by alien taxa tolerant of anthropogenically altered ecosystems (Grimm et al. 2008). In nine cities studied by Coles et al. (2012), these terrestrial changes consistently resulted in loss of sensitive taxa, beginning at the earliest stages of urbanization (i.e., no resistance to low levels of development). Biological degradation continued at the highest levels of urbanization studied (i.e., no exhaustion threshold), suggesting that resource managers could obtain biological benefits from any appropriate rehabilitation and mitigation measures no matter the extent of catchment urbanization.

Cities often are located on floodplains, commonly at stream junctions; therefore, engineering approaches that minimize flood effects and maintain water supplies have been ubiquitous. Thus, basin-scale flood control and water supply projects are common. Impoundments designed to capture seasonal runoff and deliver water during the dry season or to produce hydropower are often located hundreds of kilometers upstream of urban areas. Such reservoirs homogenize flow regimes, simplify geomorphology, modify stream temperatures, and disrupt processes that deliver sediment and large woody material. They also disturb fish migration timing and behavior via barriers and provide refuges for alien invasive species (Columbia Basin Fish and Wildlife Authority 1991; Ligon et al. 1995; Williams et al. 1996). Frequently, river and stream banks both far from and within cities are channelized, rip-rapped, or leveed to speed water conveyance, limit channel movement, and aid navigation (Sedell and Froggatt 1984; Florsheim et al. 2008). Such 
changes can impair aquatic vertebrate and macroinvertebrate assemblages far from the impoundments and channel alterations (Poff et al. 1997).

Many current urbanization conditions are affected by historical land and water uses, particularly agriculture and channel alterations. Aboriginal humans altered natural flora and fauna through harvest, fire, and agriculture, and they also built canals and ditches that likely altered aquatic biota locally (Denevan 1992, 2011; Delcourt and Delcourt 2004). Intensive hydraulic engineering projects existed centuries ago in the Americas (Marsh 1976; Helfman 2007; Walter and Merritts 2008) and millennia ago in Europe (Quintela et al. 1987) and Asia (Temple 2007). Thus, the landscapes upon which many cities are built already had been transformed by prior land uses (Harding et al. 1998; Van Sickle et al. 2004; Brown et al. 2009). However, urbanization stresses stream ecosystems to a greater degree than most types of agriculture (Steedman 1988; Wang et al. 2000; Rawer-Jost et al. 2004; Trautwein et al. 2011; Ligeiro et al. 2013). In any case, cumulative effects of land cover changes, from natural vegetation to agriculture to urban, reduce the capabilities of streams to support their native biota (Stanfield and Kilgour 2006; Stanfield and Jackson 2011; Stanfield 2012).

Since the industrial revolution, effects of urbanization accelerated, intensified, and became much more extensive (Petts 1989). Many urban streams now occur only within underground pipes or concrete canals. Urban rivers are typically channelized, rip-rapped, and leveed; littoral zones of residential lakes now have shorelines converted to docks or retaining walls; and oncedense riparian forests are converted to park-like savanna. Navigable estuaries are regularly dredged, with shoreline wetlands converted to wharfs, seawalls, and commercial enterprises. For many urban dwellers these highly altered waterscapes form their images of a typical stream, river, lake, or estuary because they are founded on what they first experienced as youths or they are the only aquatic ecosystems they know (Pauly 1995; Figure 1). However, professional fisheries biologists, aquatic ecologists, and conservationists have different images and expectations for water bodies because of the many ecosystem services they provide (Costanza et al. 1997; Ervin et al. 2012). So what can we do about it? We offer a how-to approach based on identifying root causes and their scale.

\section{REHABILITATING EFFECTS OF EXISTING URBAN AREAS ON AQUATIC ECOSYSTEMS}

In this section, we first discuss the general goals of rehabilitating aquatic ecosystems and the limitations of doing so. These limitations include the many existing physical and chemical constraints resulting from urban infrastructure, the complex interwoven types of urban pressures, and the site-scale versus catchment- or basin-scale approaches for rehabilitation. We then discuss four major rehabilitation approaches: reestablishing natural land cover, wastewater and stormwater management, recovering hydrological connectivity and geomorphic complexity, and, finally, small-scale approaches such as bank stabilization (Table 1; IMST 2010).

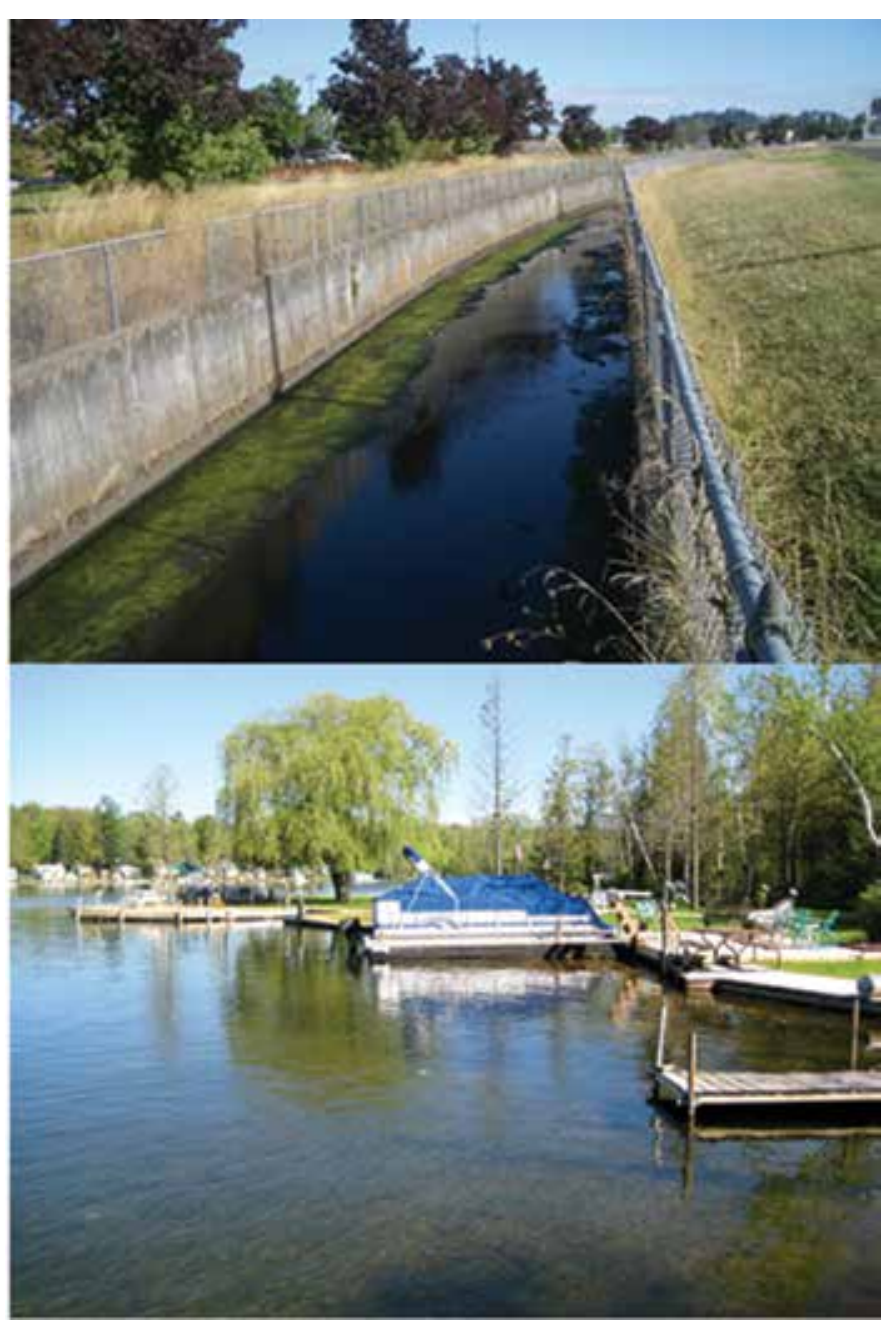

Figure 1. Top: Amazon Creek, Eugene, Oregon; bottom: Townline Lake, Clare County, Michigan.

\section{The Goal Is to Restore Processes, Not Specific Habitats}

The typical objective of most rehabilitation projects is short-term physical habitat improvement. However, the primary goal of restoration is not to jump in and create a habitat but to regain historical ecological structure by naturalizing ecosystem processes that support stable flow regimes, instream habitat connectivity, riparian vegetation, and water quality (Roni et al. 2002; Beechie et al. 2008). An additional goal is to make waters safe for body contact as prescribed by the Clean Water Act in the United States (U.S.C. $33 \S 1251$ ) or the Water Framework Directive in the European Union (European Commission 2000).

Of course, in most urban areas, natural processes are highly constrained by infrastructure (Carpenter et al. 2003; Booth 2005; Bernhardt and Palmer 2007), pollution sources (Paul and Meyer 2001), and substantial geomorphic alterations (Jennings et al. 1999, 2003; Brown et al. 2005; Walsh et al. 2005; Chin 2006; T. B. Francis and Schindler 2006; Kaye et al. 2006; R. A. Francis 2012). Consequently, aquatic ecosystems in urban areas cannot be restored to completely unimpaired conditions, but they can be rehabilitated to support desirable biota and water quality (National Research Council 1996; Booth 2005; 
Table 1. Common site-scale rehabilitation techniques applied in urban areas.

\begin{tabular}{|l|}
\hline Bank stabilization \\
\hline Erosion control focused on stream banks and shorelines \\
\hline Rip-rap, geotextiles, retaining walls, sea walls \\
\hline Planting riparian areas and shorelines with native woody plants or grasses \\
\hline Removal of alien invasive riparian plants \\
\hline Hydrological connectivity \\
\hline Improved fish passage at dams \\
\hline Daylighting of piped streams \\
\hline Dam and culvert removal and retrofitting \\
\hline Rip-rap, retaining wall, and seawall removal \\
\hline Levee and dike breaching and setbacks \\
\hline Meander and wetland creation \\
\hline Off-channel habitat and floodplain reconnection \\
\hline Decreasing the amount of impervious surfaces \\
\hline Hydromorphological complexity \\
\hline Placement of large wood, gabions, boulders, or gravel in stream channels \\
\hline Placement of large wood and brush in lakes and estuaries \\
\hline Aquatic macrophyte reestablishment in lakes and estuaries \\
\hline Wastewater and storm water management \\
\hline Wastewater (industrial, institutional, and domestic) collection and treatment \\
\hline Storm water collection, separation, and treatment \\
\hline Erosion control focused on uplands \\
\hline Reducing the amount of impervious surfaces \\
\hline Increasing evapotranspiration and infiltration of stormwater \\
\hline Reestablishing wetlands and riparian vegetation \\
\hline Installing green roofs, temporary ponds, bioswales, and rain gardens \\
\hline
\end{tabular}

Simenstad et al. 2005; Roni et al. 2008; Coles et al. 2012). The key is to understand at what scale problems are occurring and then apply a correct prescription that matches the scale of the problem.

Storm water must be controlled at its source (i.e., the catchment), which involves protections via land-use planning and regulation rather than attempts to rehabilitate degraded channels

\section{Know Your Scale}

Urbanization alters the biota via multiple pathways operating simultaneously at multiple scales (Figure 2). For example, the presence of a city on a river may result in a local physical or chemical barrier to fish migration that also alters fish populations far from those barriers (e.g., Cooke et al. 2004; Regier et al. 2013). Conversely, well-meaning mitigation projects are implemented at the site or reach scale in streams, lakes, and rivers, when many of the limiting factors are occurring at the watershed scale (e.g., Fausch et al. 2002; Roni et al. 2002; Scott et al. 2002; Strayer et al. 2003; Wang et al. 2003, 2011; Moerke and Lamberti 2006; Beechie et al. 2010; Regier et al. 2013). This is not to say that local projects are meaningless because they can have cumulative effects, especially when it comes to watershed rehabilitation or managing stormwater (Stanfield 2012).
Typically, however, rehabilitation is planned and implemented at the site $(10 \mathrm{~s}$ to $100 \mathrm{~s}$ of meters $)$ or segment $(1,000 \mathrm{~s}$ of meters to kilometers) scale. Stanfield (2012) suggested that assessing multiple sites along a segment can guide when and where local rehabilitation may be effective. However, it is almost always more effective to perform rehabilitation at watershed or basin scales, with a focus on recovering natural flow regimes (e.g., Frissell and Nawa 1992; Muhar 1996; Poff et al. 1997; Booth 2005; Wohl 2005; Bernhardt and Palmer 2007; Jansson et al. 2007). Therefore, the priority actions for urban rehabilitation are to (1) protect existing upstream high-quality catchments and habitats and (2) reestablish ecosystem processes and connectivity in the altered places (especially water quality and hydrological regime), before attempting to rehabilitate specific sites lower in the watershed (National Research Council 1992, 1996; Booth et al. 2004; Booth 2005; Roni et al. 2002, 2008; Bernhardt and Palmer 2007; Beechie et al. 2008). These are also precepts proposed by McHarg (1969) and Poff et al. (1997), which are similar to recommendations by Noss (2000) for maintaining ecological integrity at regional scales. Of course, resource managers must recognize that lag times for responses may range from 1 to 100 years or longer (Roni et al. 2002, 2008; Bernhardt and Palmer 2007; Beechie et al. 2008), and results may not be evident immediately. In the following five subsections we summarize the major rehabilitation techniques and their known limitations (Table 1).

\section{First: Rehabilitate the Watershed}

Watershed rehabilitation involves two distinct issues: management of natural land cover and managing stormwater entering via rapid runoff from impervious surfaces.

\section{Natural Land Cover}

In forested ecosystems, watersheds that have experienced timber harvest or conversion to agriculture have generally higher bedloads, embeddedness, sediment loads, and less stable flows (Sutherland et al. 2002). We note that this is the natural condition for streams in dryer ecosystems (Dodds et al. 2004), but most resource managers in temperate regions would likely view achieving a high percentage of native vegetative cover within a watershed as beneficial. However, achieving that goal is challenging from multiple perspectives.

First, watersheds vary in size and complexity and span multiple social, economic, and political boundaries with different human densities, cultural values, and land uses. This makes coordination difficult and regulatory approaches problematic. The solution is often achieved through independent watershed councils that promote stewardship and coordination (e.g., Huron River Watershed Council 2013), but rehabilitating natural land cover requires participation by not only public lands managers but in some cases thousands of private landowners.

A second issue is that it is very difficult to relate specific management actions to outcomes. Most watershed rehabilitation 


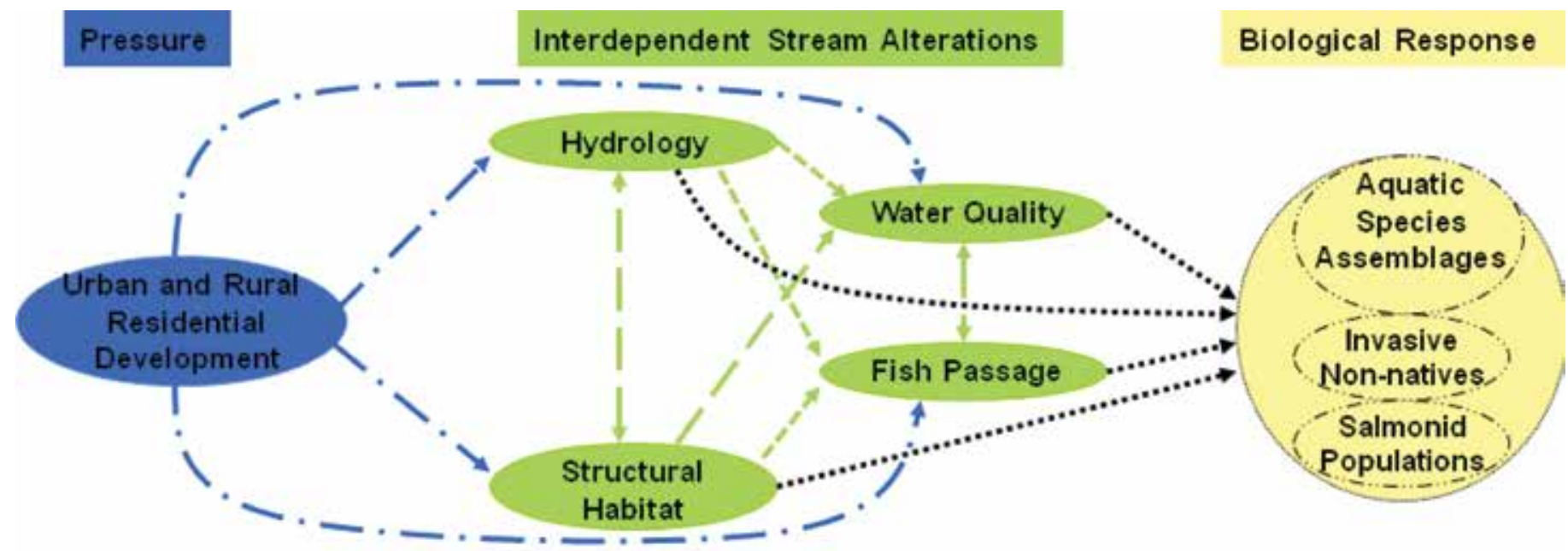

Figure 2. Interrelationships between urbanization pressures, interdependent stream alterations, and biological responses (IMST 2010).

efforts focus on encouraging riparian rehabilitation or best management practices that minimize agricultural runoff or erosion, the former because benefits are disproportionately large for the land area conserved (Quinn et al. 2001) and the latter because conversion of land to less-developed land covers is impractical (Allan 2004). However, the relationship between agricultural land cover and stream conditions is best described as highly variable with nonlinear relationships occurring at multiple scales. Some have reported that agricultural land use seems to have few effects on streams until about $30 \%$ to $50 \%$ of the watershed is farmed (e.g., Allan 2004), whereas Wang et al. (1997) reported high fish index of biotic integrity scores at sites with $80 \%$ agriculture. However, Trautman (1957) noted the demise of sensitive Ohio fishes in watersheds that experienced any loss of forest cover, and Gammon (2005) described how the Wabash River and its fish assemblages were altered soon after the land was cleared for farming. Apparently, other factors are at play, including what one uses as reference conditions and indicators.

So what are resource managers to do? It may be best to focus on riparian rehabilitation because that habitat has the most well-documented effects on stream condition (Naiman and Decamps 1997), and it also confers local habitat benefits at the reach scale (Brewer 2013). However, we note three caveats: (1) riparian rehabilitation can take many forms, depending on local physiographic conditions (a.k.a. one size fits none; Allan 2004); (2) in many watersheds extensive impervious surface coverage can override riparian services (Coles et al. 2012); and (3) extensive pipe networks can bypass riparian zones (Brewer 2013).

\section{Storm Water}

Storm water management is critical to small urban streams because runoff effects are especially severe. Some studies suggest that beyond 5\%-15\% urbanization diversity declines rapidly (Paul and Meyer 2001) because of the presence of impervious surfaces that result in rapid runoff (flashiness) that affects bank stability, hydrological connectivity, and hydromorphological complexity. To be effective, storm water must be controlled at its source (i.e., the catchment), which involves protections via land-use planning and regulation rather than attempts to rehabilitate degraded channels (Cairns 1989; Booth et al. 2004). Although a serious problem, there are a variety of prescriptions available.

The key to storm water management is to break the direct connection between the impervious surface and the stream (Cairns and Palmer 1995). There are a variety of available techniques: reconnecting stream channels to their floodplains, wetland and mini-natural area creation, reestablishing riparian vegetation, reducing the amount of impervious surfaces, and installation of green roofs, temporary ponds, bioswales, and rain gardens (Booth et al. 2004; Brand and Snodgrass 2010; IMST 2010; Schaeffer et al. 2012; City of Portland 2012a; Yeakley et al., 2014). These techniques function by increasing evapotranspiration and infiltration to the groundwater while reducing the volume of water routed directly into streams. Implementation of such green infrastructure also sequesters pollutants that might be flushed directly in high concentrations; however, Pataki et al. (2011) reported that bioswales may be nutrient sources depending on their management.

Storm water management has the added benefit of serving as aquatic habitat. Brand and Snodgrass (2010) determined that storm water retention ponds supported more amphibian breeding and rearing than natural wetlands, which were intermittently wet. Schaeffer et al. (2012) reported that a carefully designed and managed storm water retention pond provided habitat for 9 years for three regionally rare fish species that require clear water and dense aquatic macrophytes.

\section{Second: Further Improve Wastewater Treatment}

There is ample evidence that wastewater treatment benefits stream assemblages. In most developed nations, sewage and industrial effluent treatment have become commonplace, reducing waterborne diseases, improving water quality, providing opportunities for water-based recreation, and rehabilitating aquatic biological assemblages. Gammon (1976) and Hughes and Gammon (1987), respectively, reported only minor effects 
on fish assemblages exposed to treated urban wastewaters along $340 \mathrm{~km}$ of the Wabash River, Indiana, and $280 \mathrm{~km}$ of the Willamette River, Oregon - although both systems also endured agricultural pollution and channel modification. Weinbauer et al. (1980) found significantly improved water quality, fisheries, and aquatic biota in a $112-\mathrm{km}$ reach of the Wisconsin River, Wisconsin, following treatment of paper and pulp mill effluents. Yoder et al. (2005) reported substantial improvement in Ohio fish assemblages following 20 years of increasingly improved urban sewage treatment. Mulvey et al. (2009) found that the major stressors on stream biotic assemblages in the Willamette Basin, Oregon, were excess temperature, riparian disturbance, and streambed instability, rather than urban sewage.

Although wastewater treatment is effective, we note that it is not universal and many rivers in developing nations suffer from severe pollution. Massoud et al. (2009) concluded that central wastewater treatment options in developing nations were inadequate because of infrastructure expense (especially collection costs); they suggested that decentralized strategies would be far more effective. However, Paulo Pompeu (Departmento de Biologia, Universidade Federal de Lavras, Lavras, Minas Gerais, Brazil, unpublished data) has found that secondary treatment of $70 \%$ of the sewage of the Belo Horizonte Metropolitan Region resulted in substantial recovery of the fish assemblage of the Rio das Velhas.

Even though most wastewater in developed nations is treated, two major problems remain. First, storm water flows (containing nutrients and toxins) can rapidly overwhelm treatment facilities, because in many cases storm water and wastewater systems are combined, and untreated water is released during storm events (Field and Struzenski 1972). Because flow separation is problematic and expensive, wet weather retrofits are often applied (Szabo et al. 2005). Second, treated wastewaters deliver untreated personal care products, pharmaceuticals, hormones, fire retardants, plasticizers, property maintenance chemicals, nanoparticles, heavy metals, solvents, and organochlorines (Dunham, 2014; Foster et al., 2014). Up to 200 of these largely unregulated and unmonitored emerging contaminants (many of which are endocrine disruptors) are released by wastewater treatment plants and in storm waters (Ritter et al. 2002). In addition, streams and lakes receiving treated wastewaters still experience increased nutrient loadings, especially where wastewaters comprise much of the flow. In any case, urban managers can become familiar with wastewater systems in their jurisdictions, implement techniques for removing untreated chemicals from the waste stream by regulation and treatment, and know how those systems are operated and their limitations.

\section{Third: Rehabilitate Longitudinal, Lateral, and Vertical Hydrological Connectivity}

Improvements in hydrological connectivity result in increased movement of water, sediment, wood, and biota longitudinally, horizontally, and vertically (Pess et al. 2005a). Dam and culvert removal - or retrofitting-improves longitudinal connectivity and fish passage and downstream movement of sediment and large wood (Pess et al. 2005b; Price et al. 2010). Most studies we reviewed have been in forested areas where fish showed rapid positive responses to such changes when those improvements were properly designed; that is, culverts were appropriate for all life stages and most flows (Beechie et al. 2008; Roni et al. 2008). However, urban dam removals and modifications also improve fish passage (Blough et al. 2004).

Improved horizontal connectivity rehabilitates floodplains through levee breaching or setbacks, rip-rap removal, meander creation, and off-channel habitat reconnection (Pess et al. 2005a). Most studies we examined have involved rural and forested streams, and the majority indicated improved physical or biological conditions (Beechie et al. 2008; Roni et al. 2008) — and some studies have found positive effects in urban environments. Levell and Chang (2008) reported physical improvements 2 years after channel restructuring relative to an urban site but found less channel and substrate stability than in a nonurban reference site. Kaushal et al. (2008) reported that a rehabilitated reach of a Baltimore, Maryland, stream had significantly lower nitrate concentrations than an unrehabilitated reach of the same stream. Daylighting (reexposing piped streams to allow flooding and riparian vegetation) has occurred in several U.S. streams, but too few have been monitored to arrive at conclusions concerning ecological effects (Bucholz and Younos 2007). The greatest challenge is that urban infrastructure may constrain such measures (Brown et al. 2009; IMST 2010), but we believe that opportunities exist in many cities that have abandoned or neglected waterfronts and riparian zones. Those areas might be rehabilitated as public green spaces within the historic floodplain (City of Portland 2012b; Yeakley et al., in press).

Vertical connectivity is the exchange between groundwater and surface water in aquatic systems, but techniques for rehabilitating vertical connectivity rarely have been evaluated (Boulton 2007). Kaushal et al. (2008) reported that groundwater in a rehabilitated Baltimore, Maryland, stream reach had significantly lower nitrate concentrations and higher denitrification rates than in an unrehabilitated reach of the same stream. Denitrification was significantly higher in reaches where rehabilitation promoted overland flooding and seepage to groundwater versus seepage in rehabilitated reaches that were unconnected to their floodplains. Groffman et al. (2003) also found that denitrification potential decreased with channel incision and lowered water tables in urban riparian zones. In addition, increased vertical and horizontal connectivity with the water body, as opposed to stream incision or lake drawdown, is necessary for rehabilitating and sustaining riparian woody vegetation versus upland vegetation (Scott et al. 1999; Groffman et al. 2003; Kaufmann et al., in press). We note that among the major rehabilitation techniques, improved hydrological connectivity frequently shows the most immediate responses in fish passage and water quality improvement. 


\section{Fourth: Improve Hydromorphological Complexity}

Common hydromorphological rehabilitation techniques include placement of large wood, boulders, or gravel into stream channels. In forest streams, those alterations usually increased physical habitat complexity, but their biological effects are uncertain because of insufficient monitoring, method and stream variability, and study design flaws that make increased fish production indistinct from increased fish concentration (e.g., Roni et al. 2005, 2006, 2008; Thompson 2006; Stewart et al. 2009; Whiteway et al. 2010). In addition, urban streams experience more flashiness and poorer water quality than forest streams, which together may override hydromorphological complexity (Larson et al. 2001; Booth 2005; Brewer 2013). Most studies reviewed suggest that local rehabilitation actions have little effect. Larson et al. (2001) reported that adding large wood did not improve benthic macroinvertebrate assemblages in Washington urban streams. Gravel augmentation in a highly disturbed California river increased Chinook Salmon (Oncorhynchus tshawytscha) spawning activity (Merz and Setka 2004) and eggto-alevin survival (Merz et al. 2004) but not macroinvertebrate densities (Merz and Ochikubo Chan 2005). Violin et al. (2011) found no differences between macroinvertebrate assemblages and instream physical habitat of rehabilitated versus degraded urban streams in the North Carolina Piedmont. In summary, restoration of local structural complexity is unlikely to provide benefits and unlikely to persist if flow modifications and hydrological connectivity are not also addressed (Frissell and Nawa 1992; DeGasperi et al. 2009). The rare exceptions may be cases where a stream is so degraded that all within-channel habitat is lacking, but we note that those streams are likely experiencing large-scale problems as well.

\section{Fifth: Last and Least, Stabilize Banks}

Several types of erosion control techniques (rip-rap, geotextiles, gabions, retaining walls, sea walls) are employed more to protect economically valuable infrastructure than to rehabilitate natural processes of channel and shoreline erosion and migration. Such techniques transmit the energy of moving water downstream or down current to other shorelines and river banks. Because these bank hardening techniques are directed toward infrastructure protection and typically impair biotic condition and ecological processes (Sedell and Beschta 1991), we do not emphasize them in this review.

Riparian vegetation stabilizes banks and improves conditions for sensitive fish taxa in lakes, streams, and rivers. Vegetation plantings can decrease bank erosion and increase shredder macroinvertebrate diversity (Sudduth and Meyer 2006) while decreasing solar inputs, but the magnitudes of these effects on urban fish assemblages are uncertain. In lakes, Kaufmann et al. (in press) reported that increased littoral and riparian vegetation cover complexity was associated with increased richness of eutrophication-intolerant fish species (Figure 3A) and decreased richness of eutrophication-tolerant fish species (Figure 3B). Groffman et al. (2003) and Roni et al. (2008) emphasized that riparian vegetation is more likely to persist if flow modifications and hydrological connectivity are also addressed; however, additional studies are needed to document those assumptions. In contrast, rip-rap has an opposite effect; however, more controlled and multisite studies are needed. Schmetterling et al. (2001) reported that rip-rap reduced the development of undercut banks, gravel deposits, and riparian vegetation, which provide fish cover, and Kondolf et al. (2006) indicated that riprap increased downstream erosion in rivers.

In summary, urban water bodies cannot be restored to predisturbance conditions, but they can be improved to support desirable biota and water quality. Rehabilitation of urban aquatic ecosystems is challenging because of multiple and interacting biophysical urban constraints, as well as continuous inputs from and interactions with urban residents. Multiple rehabilitation measures taken at the catchment scale are most effective if they focus on reestablishing ecosystem processes and rehabilitating natural vegetation, hydrological regimes, and water quality - before attempting to rehabilitate degraded instream hydromorphology at the site scale. Resource managers skilled at diagnosing the scale at which problems are occurring will be able to apply the best prescription. And in urban sites, fisheries professionals working closely with urban planners and wastewater engineers will be able to ameliorate effects of storm water.

Our review focused on rehabilitation of urban streams that had been damaged previously. Urbanization is an ongoing phenomenon, with a progressively larger proportion of humans moving into urban areas that are likely to expand. Thus, more streams are likely to become urbanized in the future. Ideally, there would be a way to prevent damage inexpensively rather than repair extensive damage expensively. We will explore that topic in Hughes et al. (2014) and point to what still needs to be learned about urban streams to make mitigation more effective, including climate change and sociological issues.

\section{ACKNOWLEDGMENTS}

The funding for this article was provided by the Pacific Coastal Salmon Recovery Fund via the Oregon Watershed Enhancement Board to Oregon's Independent Multidisciplinary Science Team. Bill Stapp provided the philosophy and many of the insights and motivation for writing this article. Prior drafts received constructive reviews by Carlos Alves, George Pess, Les Stanfield, and three anonymous reviewers. 


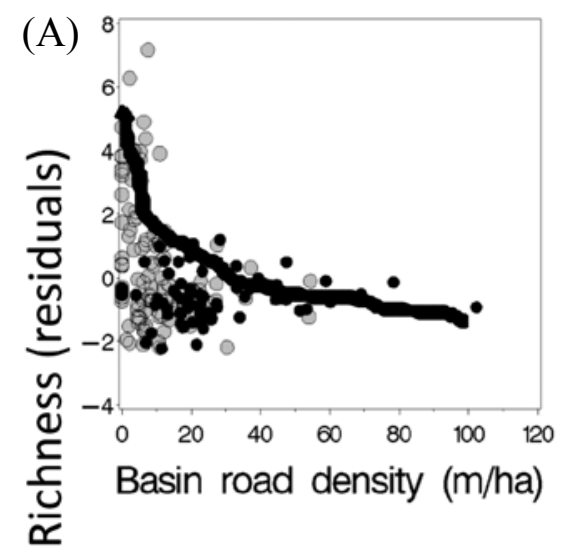

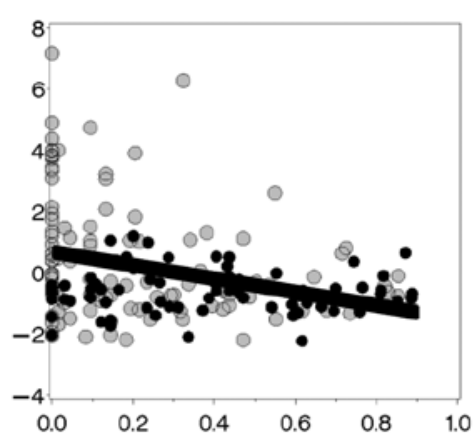

Shoreline human disturbance

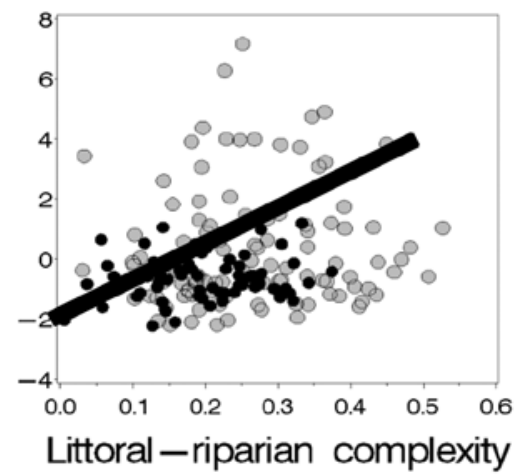

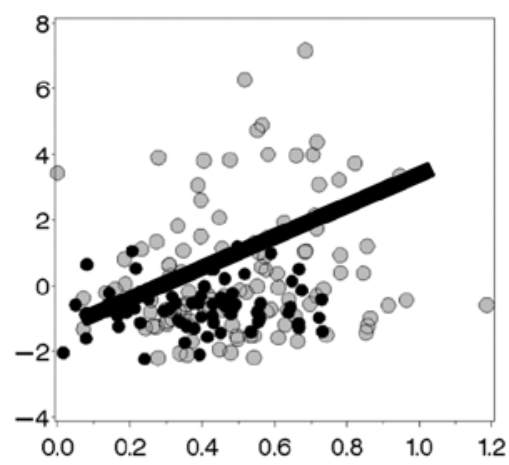

Riparian veg. complexity

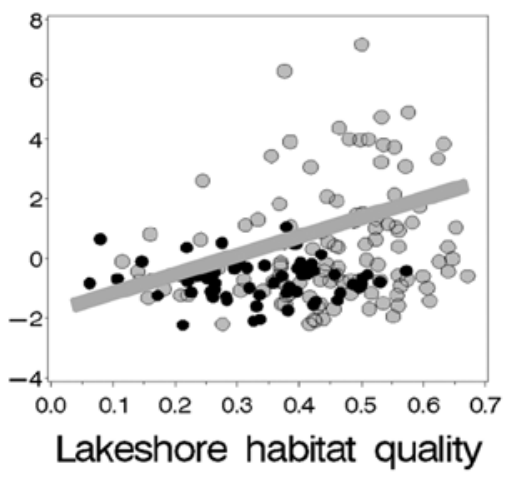

Adirondacks \& Northeast Highlands

(B)

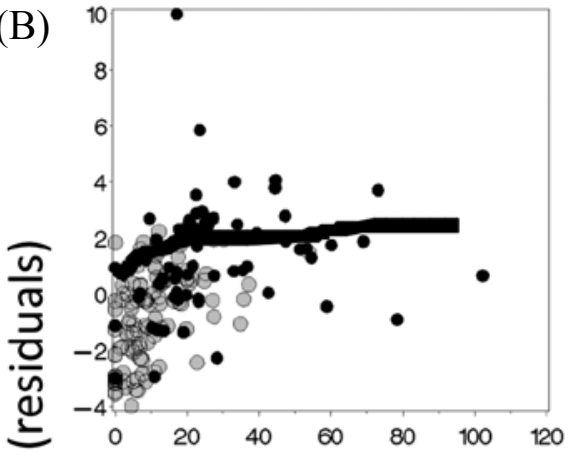

ک Basin road density $(\mathrm{m} / \mathrm{ha})$

동
- Northeast Lowlands

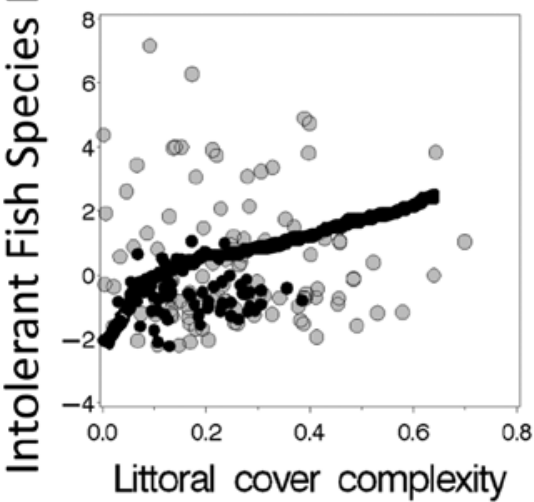

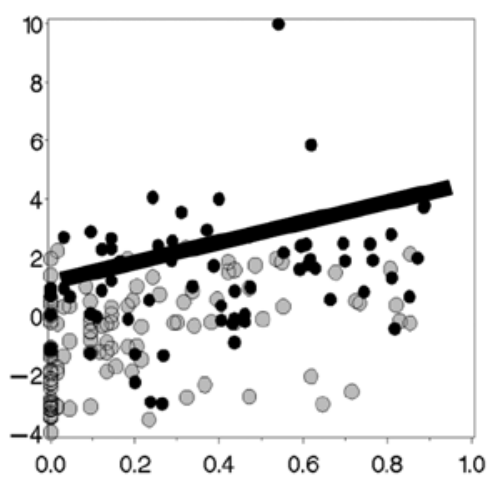

Shoreline human disturbance

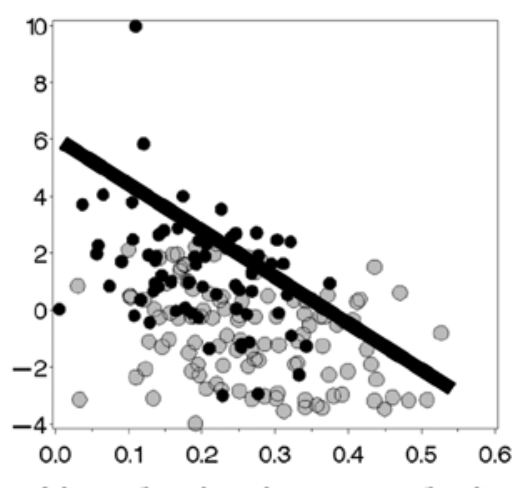

Littoral-riparian complexity

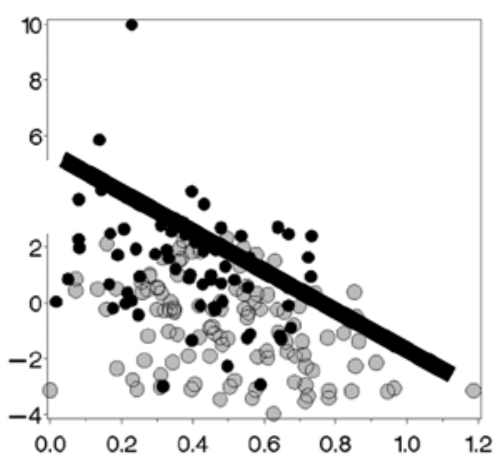

Riparian veg. complexity

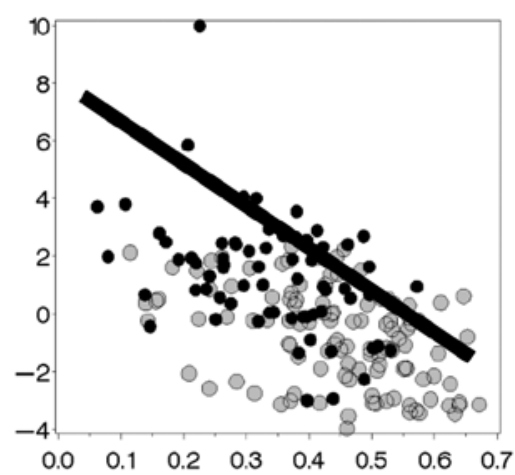

Lakeshore habitat quality

Figure 3. Responses of intolerant fish (A) and tolerant fish (B) to lake littoral and riparian condition (adapted from Kaufmann et al., in press). Richness regression residuals were used to calibrate for the effect of lake area on species richness. Lines are 95th percentile quantile regressions. 


\section{REFERENCES}

Allan, J. D. 2004. Landscapes and rivers: the influence of land use on stream ecosystems. Annual Review of Ecology and Systematics 35:257-284.

Beechie, T., G. Pess, P. Roni, and G. Giannico. 2008. Setting river restoration priorities: a review of approaches and a general protocol for identifying and prioritizing actions. North American Journal of Fisheries Management 28:891-905.

Beechie, T. J., D. Sear, J. Olden, G. R. Pess, J. Buffington, H. Moir, P. Roni, and M. M. Pollock. 2010. Process-based principles for restoring river ecosystems. BioScience 60:209-222.

Bernhardt, E. S., and M. A. Palmer. 2007. Restoring streams in an urbanizing world. Freshwater Biology 52:738-751.

Blough, H., K. Hyatt, M. Gessner, V. Poage, A. Creamer, C. Lenhart, J. Geiger, J. Rosa, W. Laney, T. Bigford, D. Pender, T. Essington, and J. Lowery. 2004. Dam removal. AFS Policy Statement 32. Available: http://fisheries.org/docs/policy_statements/policy_32f.pdf. (December 2013).

Booth, D. B. 2005. Challenges and prospects for restoring urban streams: a perspective from the Pacific Northwest of North America. Journal of the North American Benthological Society 24:724-737.

Booth, D. B., D. Hartley, and R. Jackson. 2002. Forest cover, impervious-surface area, and the mitigation of stormwater impacts. Journal of the American Water Resources Association 38:835-845.

Booth, D. B., J. R. Karr, S. Schauman, C. P. Konrad, S. A. Morley, M. G. Larson, and S. J. Burges. 2004. Reviving urban streams: land use, hydrology, biology, and human behavior. Journal of the American Water Resources Association 40:1351-1364.

Boulton, A. J. 2007. Hyporheic rehabilitation in rivers: restoring vertical connectivity. Freshwater Biology 52:632-650.

Brand, A. B., and J. W. Snodgrass. 2010. Value of artificial habitats for amphibian reproduction in altered landscapes. Conservation Biology 24:295-301.

Brauns, M., X.-F. Garcia, N. Walz, and M. T. Pusch. 2007. Effects of human shoreline development on littoral macroinvertebrates in lowland lakes. Journal of Applied Ecology 44:1138-1144.

Brewer, S. K. 2013. Channel unit use by Smallmouth Bass: do land-use constraints or quantity of habitat matter? North American Journal of Fisheries Management 33:351-358.

Brown, L. R., T. F. Cuffney, J. F. Coles, F. Fitzpatrick, G. McMahon, J. Steuer, A. H. Bell, and J. T. May. 2009. Urban streams across the USA: lessons learned from studies in nine metropolitan areas. Journal of the North American Benthological Society 28:10511069.

Brown, L. R., R. H. Gray, R. M. Hughes, and M. R. Meador. 2005. Introduction to effects of urbanization on stream ecosystems. American Fisheries Society Symposium 47:1-6.

Bryce, S. A., R. M. Hughes, and P. R. Kaufmann. 2002. Development of a bird integrity index: using bird assemblages as indicators of riparian condition. Environmental Management 30:294-310.

Buchholz, T., and T. Younos. 2007. Urban stream daylighting case study evaluations. Virginia Water Resources Research Center, Special Report SR35-2007, Virginia Tech, Blacksburg.

Cairns, J. 1989. Restoring damaged ecosystems: is predisturbance condition a viable option? The Environmental Professional 11:152159 .

Cairns, J., and S. E. Palmer. 1995. Restoration of urban waterways and vacant areas - the first steps toward sustainability. Environmental Health Perspectives 103:452-453.

Carpenter, D. D., S. K. Sinha, K. Brennan, and L. O. Slate. 2003. Urban stream restoration. Journal of Hydraulic Engineering 129:491-493.
Chin, A. 2006. Urban transformation of river landscapes in a global context. Geomorphology 79:460-487.

City of Portland. 2012a. Chapter 2.0. Stormwater management facility design. Available: http://www.portlandoregon.gov/bes/article/55791. (December 2013).

. 2012b. Johnson Creek acquisition strategy: investing in a natural area network. Available: http:/www.portlandoregon.gov/bes/ article/387967. (December 2013).

Coles, J. F., G. McMahon, A. H. Bell, L. R. Brown, F. A. Fitzpatrick, B. C. Scudder Eikenberry, M. D. Woodside, T. F. Cuffney, W. L. Bryant, K. Cappiella, L. Fraley-McNeal, and W. P. Stack. 2012. Effects of urban development on stream ecosystems in nine metropolitan study areas across the United States. U.S. Geological Survey Circular 1373. Available: http://pubs.usgs.gov/circ/1373/. (December 2013).

Columbia Basin Fish and Wildlife Authority. 1991. Integrated system plan for salmon and steelhead production in the Columbia Basin. Northwest Power Planning Council, Portland, Oregon.

Cooke, S., S. Hinch, A. Farrell, M. LaPointe S. Jones, J. S. Macdonald, D. Patterson, M. Healey, and G. Van Der Kraak. 2004. Abnormal migration timing and high en route mortality of sockeye salmon in the Fraser River, British Columbia. Fisheries 29:(2)22-33.

Costanza, R., R. D’Arge, R. De Groot, S. Farber, M. Grasso, B. Hannon, K. Limburg, S. Naeem, R. V. O’Neill, J. Paruelo, R. G. Raskin, P. Sutton, and M. Van Den Belt. 1997. The value of the world's ecosystem services and natural capital. Nature 387:253-260.

DeGasperi, C. L., H. B. Berge, K. R. Whiting, J. L. Burkey, J. L. Cassin, and R. Fuerstenberg. 2009. Linking hydrologic alteration to biological impairment in urbanizing streams of the Puget Lowland, King County, Washington. Journal of the American Water Resources Association 45:512-533.

Delcourt, P. A., and H. R. Delcourt. 2004. Prehistoric Native Americans and ecological change: human ecosystems in eastern North America since the Pleistocene. Cambridge University Press, Cambridge, England.

Denevan, W. M. 1992. The pristine myth: the landscape of the Americas in 1492. Annals of the Association of American Geographers $82: 369-385$

. 2011. The pristine myth revisited. The Geographical Review 4:576-591.

Dodds, W. K., K. Guido, M. R. Whiles, K. M. Fritz, and W. J. Matthews. 2004. Life on the edge: the ecology of Great Plains prairie streams. BioScience 54:205-216.

Dunham, S. 2014. Wastewater treatment and the urban aquatic environment. Pages 145-154 in J. A.Yeakley, K. G. Maas-Hebner, and R. M. Hughes, editors. Wild salmonids in the urbanizing Pacific Northwest. Springer, New York.

Ervin, D., D. Brown, H. Chang, V. Dujon, E. Granek, V. Shandas, and A. Yeakley. 2012. Managing ecosystem services supporting urbanizing areas. Solutions 6:74-86.

European Commission. 2000. The EU Water Framework Directive integrated river basin management for Europe. Directive 2000/60/ EC. Available: http://ec.europa.eu/environment/water/waterframework/info/intro_en.htm. (December 2013).

Fausch, K. D., C. E. Torgersen, C. V. Baxter, and H. W. Li. 2002. Landscapes to riverscapes: bridging the gap between research and conservation of stream fishes. BioScience 52:483-498.

Field, R., and E. J. Struzenski, Jr. 1972. Management and control of combined sewer overflows. Journal of the Water Pollution Control Federation 44:1393-1415.

Florsheim, J. K., J. F. Mount, and A. Chin. 2008. Bank erosion as a desirable attribute of rivers. BioScience 58:519-529.

Foster, E., L. Curtis, and D. Gunderson. 2014. Toxic contaminants in the urban aquatic environment. Pages 123-144 in J. A. Yeakley, K. G. 
Maas-Hebner, and R. M. Hughes, editors. Wild salmonids in the urbanizing Pacific Northwest. Springer, New York.

Francis, R. A. 2012. Positioning urban rivers within urban ecology. Urban Ecosystems 15:285-291.

Francis, T. B., and D. E. Schindler. 2006. Degradation of littoral habitats by residential development: woody debris in lakes of the Pacific Northwest and Midwest, United States. Ambio 35:274-280.

Frissell, C. A., and R. K. Nawa. 1992. Incidence and causes of physical failure of artificial habitat structures in streams of western Oregon and Washington. North American Journal of Fisheries Management 12:182-197.

Gammon, J. R. 1976. The fish populations of the middle $340 \mathrm{~km}$ of the Wabash River. Purdue University Water Resources Research Center, Technical Report 86, West Lafayette, Indiana.

- 2005. Wabash River fishes from 1800 to 2000. Historical changes in large river fish assemblages of the Americas. American Fisheries Society Symposium 45:365-381.

Grimm, N. B., S. H. Faeth, N. E. Golubiewski, C. L. Redman, J. Wu, X. Bai, and J. M. Briggs. 2008. Global change and the ecology of cities. Science 319:756-760.

Groffman, P. M., D. J. Bain, L. E. Band, K. T. Belt, G. S. Brush, J. M. Grove, R. V. Pouyat, I. C. Yesilonis, and W. C. Zipperer. 2003. Down by the riverside: urban riparian ecology. Frontiers in Ecology and the Environment 1:315-321.

Harding, J. S., E. F. Benfield, P. V. Bolstad, G. S. Helfman, and E. B. D. Jones. 1998. Stream biodiversity: the ghost of land use past. Proceedings of the National Academy of Sciences 95:14843-14847.

Helfman, G. S. 2007. Fish conservation: a guide to understanding and restoring global aquatic biodiversity and fishery resources. Island Press, Covelo, California.

Hennings, L. A., and W. D. Edge. 2003. Riparian bird community structure in Portland, Oregon: habitat, urbanization, and spatial scale patterns. The Condor 105:288-302.

Hook, A. M., and J. A. Yeakley. 2005. Stormflow dynamics of dissolved organic carbon and total dissolved nitrogen in a small urban watershed. Biogeochemistry 75:409-431.

Hughes, R. M., S. Dunham, K. G. Maas-Hebner, J. A. Yeakley, C. B. Schreck, M. Harte, N. Molina, C. C. Shock, and V. W. Kaczynski. 2014. A review of urban water body challenges and approaches: 2 . Mitigation and research needs. Fisheries 39(1):30-40.

Hughes, R. M., and J. R. Gammon. 1987. Longitudinal changes in fish assemblages and water quality in the Willamette River, Oregon. Transactions of the American Fisheries Society 116:196-209.

Huron River Watershed Council. 2013. Protecting the river since 1965. Available: http://www.hrwc.org. (December 2013).

IMST (Independent Multidisciplinary Science Team). 2010. Urban and rural-residential land uses: their role in watershed health and the rehabilitation of Oregon's wild salmonids. Oregon Watershed Enhancement Board, IMST Technical Report 2010-1, Salem. Available: http://www.fsl.orst.edu/imst/reports/2010-1.pdf. (December 2013).

. 2012. Urban and rural-residential land uses in Oregon: a synthesis of an IMST technical workshop on watershed functions and salmonid recovery. Oregon Watershed Enhancement Board, IMST Technical Report 2012-1, Salem. Available: http:/www.fsl.orst. edu/imst/reports/2012-1.pdf. (December 2013).

Jansson, R., C. Nilsson, and B. Malmqvist. 2007. Restoring freshwater ecosystems in riverine landscapes: the roles of connectivity and recovery processes. Freshwater Biology 52:589-596.

Jennings, M. J., M. A. Bozek, G. R. Hatzenbeler, E. E. Emmons, and M. D. Staggs. 1999. Cumulative effects of incremental shoreline habitat modification on fish assemblages in north temperate lakes. North American Journal of Fisheries Management 19:18-27.
Jennings, M. J., E. E. Emmons, G. R. Hatzenbeler, C. Edwards, and M. A. Bozek. 2003. Is littoral habitat affected by residential development and land use in watersheds of Wisconsin lakes? Lake and Reservoir Management 19:272-279.

Kaufmann, P. R., R. M. Hughes, T. R. Whittier, S. A. Bryce, C. W. Seeliger, and S. G. Paulsen. In press. Relevance of lake physical habitat assessment indices to fish and riparian birds. Lake and Reservoir Management.

Kaushal, S. S., P. M. Groffman, P. M. Mayer, E. Striz, and A. J. Gold. 2008. Effects of stream restoration on denitrification in an urbanizing watershed. Ecological Applications 18:789-804.

Kaye, J. P., P. M. Groffman, N. B. Grimm, L. A. Baker, and R. V. Pouyat. 2006. A distinct urban biogeochemistry? Trends in Ecology and Evolution 21:192-199.

Kondolf, G. M., A. J. Boulton, S. O’Daniel, G. C. Poole, F. J. Rahel, E. H. Stanley, E. Wohl, A. Bång, J. Carlstrom, C. Cristoni, H. Huber, S. Koljonen, P. Louhi, and K. Nakamura. 2006. Process-based ecological river restoration: visualizing three-dimensional connectivity and dynamic vectors to recover lost linkages. Ecology and Society 11(2), article 5 .

Larson, M. G., D. B. Booth, and S. A. Morley. 2001. Effectiveness of large woody debris in stream rehabilitation projects in urban basins. Ecological Engineering 18:211-226.

Levell, A. P., and H. Chang. 2008. Monitoring the channel process of a stream restoration project in an urbanizing watershed: a case study of Kelley Creek, Oregon, USA. River Research and Applications 24:169-182.

Ligeiro, R., R. M. Hughes, P. R. Kaufmann, D. R. Macedo, K. R. Firmiano, A. S. Melo, and M. Callisto. 2013. Defining quantitative stream disturbance gradients and the additive role of habitat variation to explain macroinvertebrate taxa richness. Ecological Indicators 25:45-57.

Ligon, F. K., W. E. Dietrich, and W. J. Trush. 1995. Downstream ecological effects of dams: a geomorphic perspective. BioScience 45:183-192.

Marsh, G. P. 1976. The Earth as modified by human actions: man and nature. Scribner and Armstrong, New York.

Massoud, M. A., A. Tarhini, and J. A. Nasr. 2009. Decentralized approaches to wastewater treatment and management: applicability in developing countries. Journal of Environmental Management 90:652-659.

McHarg, I. L. 1969. Design with nature. Wiley, New York.

Merz, J. E., and L. K. Ochikubo Chan. 2005. Effects of gravel augmentation on macroinvertebrate assemblages in a regulated California River. River Research and Applications 21:61-74.

Merz, J. E., and J. D. Setka. 2004. Evaluation of a spawning habitat enhancement site for Chinook salmon in a regulated California river. North American Journal of Fisheries Management 24:397-407.

Merz, J. E., J. D. Setka, G. B. Pasternack, and J. M. Wheaton. 2004. Predicting benefits of spawning-habitat rehabilitation to salmonid (Oncorhynchus spp.) fry production in a regulated California river. Canadian Journal of Fisheries and Aquatic Sciences 61:14331446.

Moerke, A. H., and G. A. Lamberti. 2006. Relationships between land use and stream ecosystems: a multistream assessment in southwestern Michigan. American Fisheries Society Symposium 48:323-338.

Muhar, S. 1996. Habitat improvement of Austrian rivers with regard to different scales. Regulated Rivers: Research and Management 12:471-482.

Mulvey, M., R. Leferink, and A. Borisenko. 2009. Willamette Basin rivers and streams assessment. Oregon Department of Environmental Quality, DEQ 09-LAB-016, Portland. Available: http://www.deq. 
state.or.us/lab/wqm/docs/WillametteBasinAssessment2009.pdf. (December 2013).

Naiman, R. J. and H. Decamps. 1997. The ecology of interfaces: riparian zones. Annual Review of Ecology and Systematics 28:621-658.

National Research Council. 1992. Restoration of aquatic ecosystems: science, technology, and public policy. National Academy Press, Washington, D.C.

1996. Upstream: salmon and society in the Pacific Northwest. National Academy Press, Washington, D.C.

Noss, R. F. 2000. Maintaining the ecological integrity of landscapes and ecoregions. Pages 191-208 in D. Pimentel, L. Westra, and R. F. Noss, editors. Ecological integrity: integrating environment, conservation, and health. Island Press, Washington, D.C.

Ozawa, C. P., and J. A. Yeakley. 2007. Performance of management strategies in the protection of riparian vegetation in three Oregon cities. Journal of Environmental Planning and Management 50:803-822.

Pataki, D. E., M. M. Carreiro, J. Cherrier, N. E. Grulke, V. Jennings, S. Pinceti, R. V. Pouyat, T. H. Whitlow, and W. C. Zipperer. 2011. Coupling biogeochemical cycles in urban environments: ecosystem services, green solutions, and misconceptions. Frontiers in Ecology and the Environment 9:27-36.

Paul, M. J., and J. L. Meyer. 2001. Streams in the urban landscape. Annual Review of Ecology and Systematics 32:333-365.

Pauly, D. 1995. Anecdotes and the shifting baseline syndrome of fisheries. Trends in Ecology and Evolution 10:430.

Pess, G. R., S. A. Morley, J. L. Hall, and R. K. Timm. 2005a. Monitoring floodplain restoration. Pages 127-166 in P. Roni, editor. Monitoring stream and watershed restoration. American Fisheries Society, Bethesda, Maryland.

Pess, G. R., S. A. Morley, and P. Roni. 2005b. Evaluating fish responses to culvert replacement and other methods for reconnecting isolated aquatic habitats. Pages 267-276 in P. Roni, editor. Monitoring stream and watershed restoration. American Fisheries Society, Bethesda, Maryland.

Petts, G. E. 1989. Historical change of large alluvial rivers: Western Europe. John Wiley \& Sons, New York.

Poff, N. L., J. D. Allan, M. B. Bain, J. R. Karr, K. L. Prestegaard, B. D. Richter, R. E. Sparks, and J. C. Stromberg. 1997. The natural flow regime: a paradigm for river conservation and restoration. BioScience 47:769-784.

Price, D. M., T. Quinn, and R. J. Barnard. 2010. Fish passage effectiveness of recently constructed road crossing culverts in the Puget Sound Region of Washington State. North American Journal of Fisheries Management 30:1110-1125.

Quinn, J. M., P. M. Brown, W. Boyce, S. Mackay, A. Taylor, and T. Fenton. 2001. Riparian zone classification for management of stream water quality and ecosystem health. Journal of the American Water Resource Association 37:1509-1515.

Quintela, A. C., J. L. Cardoso, and J. M. Mascarenhas. 1987. Roman dams in southern Portugal. Water Power and Dam Construction: International (May):38-70.

Rapport, D. J., H. A. Regier, and T. C. Hutchinson. 1985. Ecosystem behavior under stress. American Naturalist 125:617-640.

Rawer-Jost, C., A. Zenker, and J. Böhmer. 2004. Reference conditions of German stream types analyzed and revised with macroinvertebrate fauna. Limnologica 34:390-397.

Regier, H. A., R. M. Hughes, and J. E. Gannon. 2013. The lake sturgeon as survivor and integrative indicator of changes in stressed aquatic ecosystems in the Laurentian Basin. Pages 27-57 in D. Dempsey and N. Auer, editors. The Great Lake Sturgeon. Michigan State University Press, East Lansing, Michigan.

Ritter, L., K. Solomon, P. Sibley, K. Hall, P, Keen, G. Mattu, and B. Linton. 2002. Sources, pathways, and relative risks of contami- nants in surface water and groundwater: a perspective prepared for the Walkerton Inquiry. Journal of Toxicology and Environmental Health, Part A 65:1-142.

Roni, P., T. J. Beechie, R. E. Bilby, F. E. Leonetti, M. M. Pollock, and G. R. Pess. 2002. A review of stream restoration techniques and a hierarchical strategy for prioritizing restoration in Pacific Northwest watersheds. North American Journal of Fisheries Management 22:1-20.

Roni, P., T. Bennett, S. Morley, G. R. Pess, K. Hanson, D. van Slyke, and P. Olmstead. 2006. Rehabilitation of bedrock stream channels: the effects of boulder weir placement on aquatic habitat and biota. River Research and Applications 22:967-980.

Roni, P., K. Hanson, and T. Beechie. 2008. Global review of the physical and biological effectiveness of stream habitat rehabilitation techniques. North American Journal of Fisheries Management 28:856-890.

Roni, P., K. Hanson, T. J. Beechie, G. R. Pess, M. M. Pollock, and D. M. Barley. 2005. Habitat rehabilitation for inland fisheries. Global review of effectiveness and guidance for rehabilitation of freshwater ecosystems. Food and Agriculture Organization of the United Nations, Fisheries Technical Paper 484, Rome, Italy.

Schaeffer, J. S., J. K. Bland, and J. Janssen. 2012. Use of a stormwater retention system for conservation of regionally endangered fishes. Fisheries 37(2):66-75.

Schmetterling, D. A., C. G. Clancy, and T. M. Brandt. 2001. Effects of riprap bank reinforcement on stream salmonids in the western United States. Fisheries 26(7):6-13.

Scott, M. C., G. S. Helfman, M. E. McTammany, E. F. Benfield, and P. V. Bolstad. 2002. Multiscale influences on physical and chemical stream conditions across Blue Ridge landscapes. Journal of the American Water Resources Association 38:1379-1392.

Scott, M. L., P. B. Shafroth, and G. T. Auble. 1999. Responses of riparian cottonwoods to alluvial water table declines. Environmental Management 23:347-358.

Sedell, J. R., and R. L. Beschta. 1991. Bringing back the "bio" in bioengineering. American Fisheries Society Symposium 10:160-175.

Sedell, J. R., and J. L. Froggatt. 1984. Importance of streamside forests to large rivers: the isolation of the Willamette River, Oregon, USA, from its floodplain by snagging and streamside forest removal. Internationale Vereinigung fuer Theoretische und Angewandte Limnologie Verhandlungen 22:1828-1834.

Simenstad, C., C. Tanneriji, C. Crandelli, J. White, and J. Corde. 2005. Challenges of habitat restoration in a heavily urbanized estuary: evaluating the investment. Journal of Coastal Research 40:6-23.

Stanfield, L. W. 2012. Reporting on the condition of stream fish communities in the Canadian tributaries of Lake Ontario, at various spatial scales. Journal of Great Lakes Research 38:196-205.

Stanfield, L. W., S. F. Gibson, and J. A. Borwick. 2006. Using a landscape approach to identify the distribution and density patterns of salmonids in Lake Ontario tributaries. Landscape influences on stream habitats and biological assemblages. American Fisheries Society Symposium 48:601-621.

Stanfield, L. W., and D. A. Jackson. 2011. Understanding the factors that influence headwater stream flows in response to storm events. Journal of the American Water Resources Association 47:315-336.

Stanfield, L. W., and B. W. Kilgour. 2006. Effects of percent impervious cover on fish and benthos assemblages and instream habitats in Lake Ontario tributaries. Landscape influences on stream habitats and biological assemblages. American Fisheries Society Symposium 48:577-599.

Steedman, R. 1988. Modification and assessment of an index of biotic integrity to quantify stream quality in Southern Ontario. Canadian Journal of Fisheries and Aquatic Sciences 45:492-501.

Stewart, G. B., H. R. Bayliss, D. A. Showler, W. J. Sutherland, and A. S. Pullin. 2009. Effectiveness of engineered in-stream structure 
mitigation measures to increase salmonid abundance: a systematic review. Ecological Applications 19:931-941.

Stranko, S. A., R. H. Hilderbrand, R. P. Morgan II, M. W. Staley, A. J. Becker, A. Roseberry-Lincoln, E. S. Perry, and P. T. Jacobson. 2008. Brook trout declines with land cover and temperature changes in Maryland. North American Journal of Fisheries Management 28:1223-1232.

Strayer, D. L., R. E. Beighley, L. C. Thompson, S. Brooks, C. Nilsson, G. Pinay, and R. J. Naiman. 2003. Effects of land cover on stream ecosystems: roles of empirical models and scaling issues. Ecosystems 6:407-423.

Sudduth, E. B., and J. L. Meyer. 2006. Effects of bioengineered streambank stabilization on bank habitat and macroinvertebrates in urban streams. Environmental Management 38:218-226.

Sutherland, A. B., J. L. Meyer, and E. P. Gardiner. 2002. Effects of land cover on sediment regime and fish assemblage structure in four southern Appalachian streams. Freshwater Biology 47:1791-1805.

Szabo, J., S. Buchberger, and P. Bishop. 2005. Performance of wet weather treatment facility for control of combined sewer overflows: case study in Cincinnati, Ohio. Journal of Environmental Engineering 131:375-386.

Temple, R. 2007. The genius of China: 3,000 years of science, discovery, and invention. André Deutsch, London.

Thompson, D. M. 2006. Did the pre-1980 use of instream structures improve streams? A reanalysis of historical data. Ecological Applications 16:784-796.

Trautman, M. B. 1957. The fishes of Ohio. The Ohio State University Press, Columbus.

Trautwein, C., R. Schinegger, and S. Schmutz. 2011. Cumulative effects of land use on fish metrics in different types of running waters in Austria. Aquatic Sciences 74:329-341.

United Nations Population Division. 2006. World urbanization prospects: the 2005 revision. United Nations, New York.

U.S.C. $33 \S 1251$. Navigation and navigable waters. Chapter 26: Water pollution prevention and control. Section 1251. Congressional declaration of goals and policy. Available: http://www.gpo.gov/ fdsys/pkg/USCODE-2011-title33/pdf/USCODE-2011-title33chap26-subchapI-sec1251.pdf. (December 2013).

Van Sickle, J., J. Baker, A. Herlihy, P. Bayley, S. Gregory, P. Haggerty, L. Ashkenas, and J. Li. 2004. Projecting the biological condition of streams under alternative scenarios of human land use. Ecological Applications 14:368-380.

Violin, C. R., P. Cada, E. B. Sudduth, B. A. Hassett, D. L. Penrose, and E. S. Bernhardt. 2011. Effects of urbanization and urban stream restoration on the physical and biological structure of stream ecosystems. Ecological Applications 21:1932-1949.

Walsh, C. J., A. H. Roy, J. W. Feminella, P. D. Cottingham, P. M. Groffman, and R. P. Morgan. 2005. The urban stream syndrome: current knowledge and the search for a cure. Journal of the North American Benthological Society 24:706-723.

Walter, R. C., and D. J. Merritts. 2008. Natural streams and the legacy of water-powered mills. Science 319:299-304.

Wang, L., D. Infante, P. Esselman, A. Cooper, D. Wu, W. Taylor, D. Beard, G. Whelan, and A. Ostroff. 2011. A hierarchical spatial framework and database for the National River Fish Habitat Condition Assessment. Fisheries 36(9):436-449.

Wang, L., J. Lyons, P. Kanehl, R. Bannerman, and E. Emmons. 2000. Watershed urbanization and changes in fish communities in southeastern Wisconsin streams. Journal of the American Water Resources Association 36:1173-1189.

Wang, L., J. Lyons, P. Kanehl, and R. Gatti. 1997. Influences of watershed land use on habitat quality and biotic integrity in Wisconsin streams. Fisheries 22(6):6-12.

Wang, L., J. Lyons, P. Rasmussen, P. Seelbach, T. Simon, M. Wiley, P. Kanehl, E. Baker, S. Niemela, and P. M. Stewart. 2003. Watershed, reach, and riparian influences on stream fish assemblages in the Northern Lakes and Forest Ecoregion, USA. Canadian Journal of Fisheries and Aquatic Sciences 60:1-15.

Weinbauer, J. D., D. A. Thiel, V. W. Kaczynski, and C. S. Martin. 1980. Receiving stream fisheries studies relative to secondary treated pulp and paper mill effluents. Tappi 63:121-125.

Whiteway, S. L., P. M. Biron, A. Zimmerman, O. Venter, and J. W. A. Grant. 2010. Do in-stream restoration structures enhance salmonid abundance? A meta-analysis. Canadian Journal of Fisheries and Aquatic Sciences 67:831-841.

Whittier, T. R., D. B. Halliwell, and S. G. Paulsen. 1997. Cyprinid distributions in northeast USA lakes: evidence of regional-scale minnow biodiversity losses. Canadian Journal of Fisheries and Aquatic Sciences 54:1593-1607.

Williams, R. N., L. D. Calvin, C. C. Coutant, M. W. Erho, Jr., J. A. Lichatowich, W. J. Liss, W. E. McConnaha, P. R. Mundy, J. A. Stanford, R. R. Whitney, D. L. Bottom, and C. A. Frissell. 1996. Return to the river: restoration of salmonid fishes in the Columbia Basin. Northwest Power Planning Council, Portland, Oregon.

Wohl, E. 2005. Compromised rivers: understanding historical human impacts on rivers in the context of restoration. Ecology and Society 10(2), article 2 .

Yeakley, J. A., K. G. Maas-Hebner, and R. M. Hughes, editors. 2014. Wild salmonids in the urbanizing Pacific Northwest. Springer, New York.

Yoder, C. O., E. T. Rankin, M. A. Smith, B. C. Alsdorf, D. J. Altfater, C. E. Boucher, R. J. Miltner, D. E. Mishne, R. E. Sanders, and R. F. Thoma. 2005. Changes in fish assemblage status in Ohio's nonwadeable rivers and streams over two decades. Historical changes in large river fish assemblages of the Americas. American Fisheries Society Symposium 45:399-430.
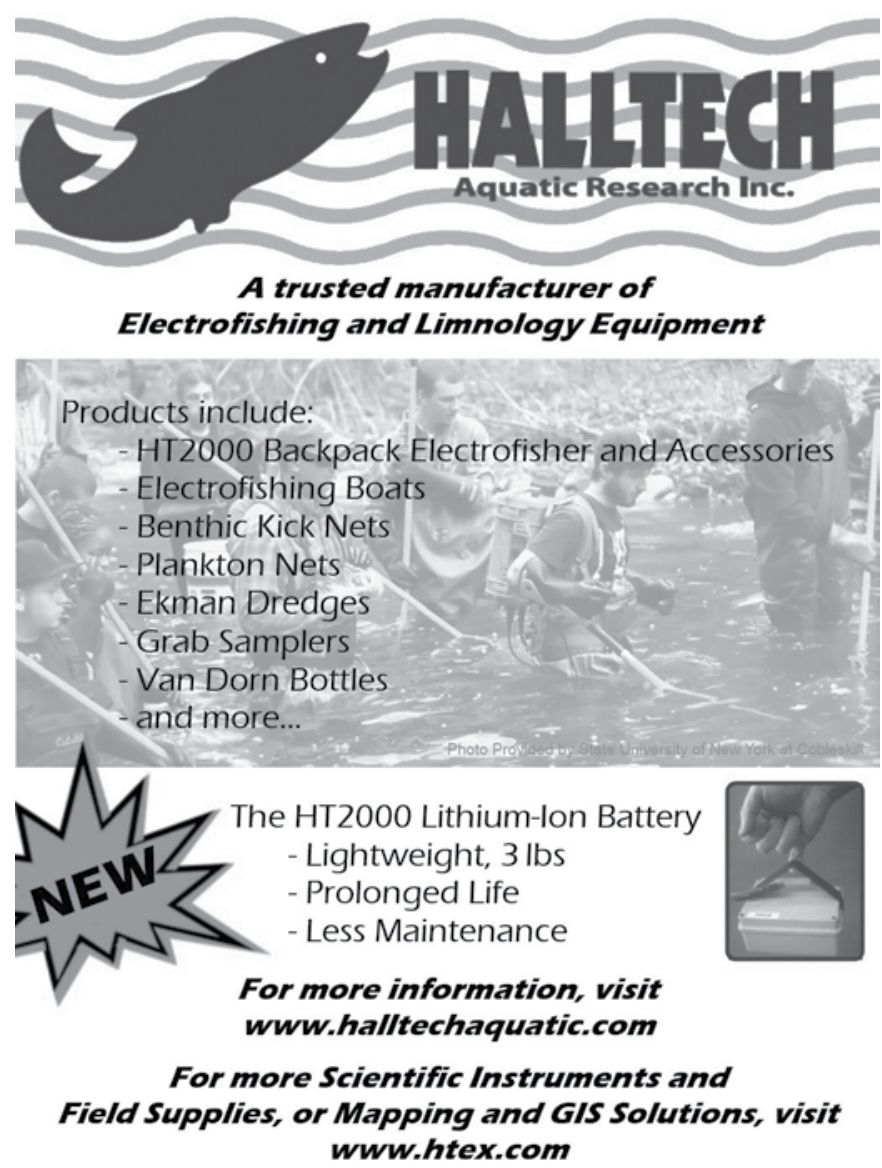